\title{
Strategie firm polskich wobec ekspansji inwestorów zagranicznych - instrumenty polityki gospodarczej
}

\section{Wstęp}

W niniejszym artykule autorzy relacjonują jeden z kilku obszarów wyników uzyskanych w efekcie realizacji projektu badawczego $\mathrm{KBN}^{*}$. Przed przystąpieniem do zreferowania osiągniętych wyników warto w kilku zdaniach przedstawić istotę projektu.

Punkt ciężkości zainteresowań omawianego projektu badawczego stanowiły procesy konfrontacji strategii polskich firm lokalnych i firm zagranicznych wchodzących do Polski w różnych formach, ze zwróceniem szczególnej uwagi na zagraniczne inwestycje bezpośrednie. Akcent położono na strategie firm lokalnych. Główne zadania badawcze sprowadzały się do udzielenia odpowiedzi na trzy pytania:

- jakie strategie firmy lokalne mogą realizować w obliczu ekspansji firm zagranicznych,

- jakie strategie realizuja,

- jakie strategie powinny realizować?

Odpowiedzi na pierwsze pytanie dotyczace możliwych strategii służyły badania literaturowe, które miały wskazać i zrekonstruować na potrzeby niniejszego projektu podstawy teoretyczne takich strategii. Innymi słowy, chodziło o identyfikację i odtworzenie założeń tych teorii ekonomicznych, które zajmuja stanowisko $\mathrm{w}$ interesującej nas sprawie oraz wyciągnięcie z nich możliwych wniosków. W grę wchodziły tutaj następujące zagadnienia:

- ujęcie internacjonalizacji i globalizacji we współczesnych teoriach przedsiębiorstwa,

- zachowania firm lokalnych a motywy i formy zagranicznych inwestycji bezpośrednich,

- zachowaniafirmlokalnychakonkurencjawewnątrz branży,

- zachowania firm lokalnych a różnice kulturowe i osobliwości zachowań inwestorów zagranicznych,

- typy zachowań firm lokalnych wobec inwestorów zagranicznych.

Odpowiedzi na drugie pytanie służyły badania empiryczne adresowane do firm polskich (lokalnych), które stanęły wobec wyzwań związanych z przyjęciem, a więc wyborem i realizacją określonych strategii w stosunku do strategii ekspansji firm zagranicznych na rynku polskim.

Badania empiryczne objęły:

- badania ankietowe 77 firm polskich należących do trzech branż: budowlanej, motoryzacyjnej oraz spożywczej,

- przygotowanie 3 studiów przypadku - 3 firmy polskie.

Odpowiedź na ostatnie, trzecie pytanie została udzielona na podstawie wniosków wynikających z przeprowadzonych badań empirycznych oraz w nawiązaniu do zaleceń wynikających ze współczesnych teorii przedsiębiorstwa oraz współczesnych doktryn i teorii polityki gospodarczej.

Wśród uzyskanych wyników należy zwrócić uwagę na kwestie polityki gospodarczej. Interesującym, a jednocześnie często niedocenianym aspektem polityki gospodarczej jest kwestia jej postrzegania przez adresatów tej polityki, czyli przez przedsiębiorstwa oraz kwestia oczekiwań formułowanych pod adresem polityki gospodarczej przez firmy. Niżej zaprezentowane są wyniki badania empirycznego przeprowadzonego w ramach przywołanego projektu badawczego $\mathrm{KBN}$.

\section{Charakterystyka badania empirycznego}

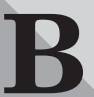

adanie empiryczne, dotyczące strategii firm polskich wobec ekspansji inwestorów zagranicznych, zostało przeprowadzone w pierwszej połowie 2004 roku wśród polskich przedsiębiorstw z branży spożywczej, budowlanej oraz motoryzacyjnej. Badane firmy w większości mają swoje siedziby w województwach: wielkopolskim, zachodniopomorskim oraz pomorskim. Głównym kryterium doboru jednostek do próby było pochodzenie kapitału, które miało znaczący wpływ na realizację zamierzonego celu, a także wyrażenie zgody na chęć uczestnictwa w badaniu (z tego wynika także metoda doboru próby).

Przy doborze przedsiębiorstw w badaniu wykorzystano najbardziej typowy przypadek nielosowego doboru próby - dobór celowy, który polegał na dość formalnym i subiektywnym wyborze jednostek do pró- 
by, w nadziei uzyskania najszerszych i najpełniejszych informacji. Z zastosowanej metody doboru próby wynikają konsekwencje związane z interpretacją uzyskanych rezultatów. Wielkość (77 firm) oraz metoda doboru próby świadczą o jej małej reprezentatywności. Wyniki badania nie mogą być zatem uogólniane dla całej populacji, lecz charakteryzują one jedynie sytuację w badanej grupie przedsiębiorstw. Największą grupę stanowily firmy należące do branży budowlanej $(40,26 \%)$, następnie spożywczej $(31,17 \%)$ i motoryzacyjnej $(28,57 \%)$. Pod względem wielkości zatrudnienia większość próby należy do grupy małych i średnich przedsiębiorstw.

Największy odsetek $(85,71 \%)$ w badanej próbie stanowią przedsiębiorstwa prywatne bez udziału kapitału publicznego. W grupie przedsiębiorstw z branży spożywczej nie znalazła się żadna firma ze 100-proc. udziałem kapitału publicznego w strukturze właścicielskiej, a trzy firmy wskazały na znacznie mniejszy jego odsetek. W branżach budowlanej oraz motoryzacyjnej w sze- ściu badanych jednostkach (po trzy w każdej branży) wskazano 100-proc. udział kapitału publicznego.

Badana grupa przedsiębiorstw to przede wszystkim przedsiębiorstwa polskie, ze 100-proc. udziałem kapitału polskiego w strukturze własnościowej. Polskie firmy stanowią $92,2 \%$ całej grupy. Nie jest to jednak w żadnym razie odzwierciedlenie sytuacji panujacej na rynku polskim. Głównym celem projektu było bowiem zbadanie zachowań polskich firm wobec ekspansji inwestorów zagranicznych, stąd do próby zostały dobrane w większości przedsiębiorstwa polskiego pochodzenia. Znalazło się w niej także pięć firm z większościowym udziałem kapitału zagranicznego istniejacych w statystykach jeszcze niedawno jako firmy polskie. Jednak przedsiębiorstwa te znalazły inwestorów zagranicznych, którzy wnieśli w strukturę własnościową obcy kapitał. Obecnie funkcjonują one na rynku już jako firmy zagraniczne.

Ze względu na to, że jednostki próby to przedsiębiorstwa reprezentowane przez przedstawicieli wyż-

Tab. 1. Przydatność i realizacja działań z zakresu polityki gospodarczej dla trzech badanych branż łącznie

\begin{tabular}{|l|}
\hline Skala ocen przydatności: \\
\hline 0 - metoda niewłaściwa \\
\hline 1 - metoda mało przydatna \\
\hline 2 - metoda przydatna \\
\hline 3 - metoda bardzo przydatna \\
\hline 4 - metoda niezbędna \\
\hline
\end{tabular}

\begin{tabular}{|l|}
\hline Skala ocen realizacji: \\
\hline 0 - całkowity brak realizacji \\
\hline 1 - słaba realizacja \\
\hline 2 - średnia realizacja \\
\hline 3 - dobra realizacja \\
\hline 4 - bardzo dobra realizacja
\end{tabular}

LW - liczba wskazań

SR - średnia arytmetyczna

SDV - odchylenie standardowe

\begin{tabular}{|c|c|c|c|c|c|c|}
\hline \multirow{2}{*}{ Działania z zakresu polityki gospodarczej } & \multicolumn{3}{|c|}{ Przydatność } & \multicolumn{3}{|c|}{ Realizacja } \\
\hline & $\mathbf{L W}$ & ŚR & SDV & LW & ŚR & SDV \\
\hline - Obniżenie stóp procentowych kredytów na cele inwestycyjne & 76 & 3,21 & 0,82 & 75 & 1,31 & 0,88 \\
\hline - Zwiększenie dostępności kredytów na cele inwestycyjne & 76 & 3,24 & 0,83 & 75 & 1,31 & 0,79 \\
\hline - Wspieranie edukacji i szkoleń & 76 & 2,64 & 0,87 & 75 & 1,23 & 0,76 \\
\hline - Obniżenie stóp podatku dochodowego & 76 & 3,24 & 0,78 & 75 & 1,31 & 0,91 \\
\hline - Wspieranie małych i średnich firm & 76 & 3,17 & 0,89 & 75 & 1,12 & 0,84 \\
\hline $\begin{array}{l}\text { - Tworzenie płaszczyzn (stowarzyszenia, zrzeszenia) wymiany wiedzy, } \\
\text { informacji i doświadczeń pomiędzy firmami polskimi i zagranicznymi }\end{array}$ & 75 & 2,32 & 1,03 & 74 & 1,15 & 0,81 \\
\hline $\begin{array}{l}\text { - Zagraniczna polityka handlowa mająca na celu likwidację administra- } \\
\text { cyjno-prawnych barier dostępu do rynków zagranicznych }\end{array}$ & 74 & 2,76 & 1,03 & 72 & 1,11 & 0,83 \\
\hline - Ubezpieczenie kontraktów eksportowych & 73 & 2,63 & 1,05 & 71 & 1,38 & 1,06 \\
\hline - Dofinansowanie kredytów eksportowych & 70 & 2,59 & 1,03 & 69 & 1,16 & 1,02 \\
\hline - Tworzenie instytucji doradztwa eksportowego & 73 & 2,32 & 1,04 & 73 & 1,19 & 0,86 \\
\hline - Tworzenie instytucji informacji rynkowej & 75 & 2,44 & 0,96 & 74 & 1,27 & 0,85 \\
\hline - Sprzyjanie napływowi zagranicznych inwestycji bezpośrednich & 74 & 2,39 & 1,19 & 71 & 1,24 & 0,85 \\
\hline - Przyspieszenie rozwoju infrastruktury & 76 & 3,08 & 0,89 & 74 & 1,14 & 0,78 \\
\hline - Interwencja w pojedynczych firmach & 73 & 1,16 & 1,11 & 73 & 0,81 & 0,70 \\
\hline $\begin{array}{l}\text { - Wykorzystanie wszelkich możliwych środków ochrony firm polskich } \\
\text { w obliczu presji konkurencyjnej firm zagranicznych }\end{array}$ & 74 & 2,12 & 1,38 & 74 & 0,88 & 0,68 \\
\hline - Selektywna polityka przemysłowa (popieranie wybranych branż) & 74 & 1,46 & 1,22 & 74 & 1,09 & 0,95 \\
\hline
\end{tabular}


Tab. 2. Przydatność i realizacja działań z zakresu polityki gospodarczej w ocenie badanych przedsiębiorstw branży spożywczej

\begin{tabular}{|c|c|c|c|c|c|c|}
\hline \multirow{2}{*}{ Działania z zakresu polityki gospodarczej } & \multicolumn{3}{|c|}{ Przydatność } & \multicolumn{3}{|c|}{ Realizacja } \\
\hline & $\mathbf{L W}$ & ŚR & SDV & $\mathbf{L W}$ & ŚR & SDV \\
\hline - Obniżenie stóp procentowych kredytów na cele inwestycyjne & 24 & 3,21 & 1,10 & 24 & 1,42 & 0,93 \\
\hline - Zwiększenie dostępności kredytów na cele inwestycyjne & 24 & 3,33 & 1,01 & 24 & 1,29 & 0,91 \\
\hline - Wspieranie edukacji i szkoleń & 24 & 3,00 & 0,98 & 24 & 0,88 & 0,68 \\
\hline - Obniżenie stóp podatku dochodowego & 24 & 3,38 & 0,97 & 24 & 1,17 & 1,09 \\
\hline - Wspieranie małych i średnich firm & 24 & 3,21 & 1,10 & 24 & 1,04 & 0,62 \\
\hline $\begin{array}{l}\text { - Tworzenie płaszczyzn (stowarzyszenia, zrzeszenia) wymiany wiedzy, } \\
\text { informacji i doświadczeń pomiędzy firmami polskimi i zagranicznymi }\end{array}$ & 24 & 2,33 & 1,27 & 24 & 1,00 & 0,72 \\
\hline $\begin{array}{l}\text { - Zagraniczna polityka handlowa mająca na celu likwidację administra- } \\
\text { cyjno-prawnych barier dostępu do rynków zagranicznych }\end{array}$ & 24 & 2,88 & 1,19 & 23 & 0,96 & 0,77 \\
\hline - Ubezpieczenie kontraktów eksportowych & 23 & 2,48 & 1,34 & 22 & 1,09 & 0,92 \\
\hline - Dofinansowanie kredytów eksportowych & 22 & 2,45 & 1,44 & 21 & 0,95 & 1,02 \\
\hline - Tworzenie instytucji doradztwa eksportowego & 23 & 2,13 & 1,18 & 24 & 1,21 & 0,88 \\
\hline - Tworzenie instytucji informacji rynkowej & 24 & 2,29 & 1,16 & 24 & 1,25 & 0,94 \\
\hline - Sprzyjanie napływowi zagranicznych inwestycji bezpośrednich & 23 & 2,09 & 1,41 & 22 & 1,41 & 0,96 \\
\hline - Przyspieszenie rozwoju infrastruktury & 24 & 3,21 & 0,93 & 24 & 1,17 & 0,82 \\
\hline - Interwencja w pojedynczych firmach & 23 & 1,26 & 1,14 & 23 & 0,87 & 0,81 \\
\hline $\begin{array}{l}\text { - Wykorzystanie wszelkich możliwych środków ochrony firm polskich } \\
\text { w obliczu presji konkurencyjnej firm zagranicznych }\end{array}$ & 23 & 2,39 & 1,62 & 23 & 1,09 & 0,73 \\
\hline - Selektywna polityka przemysłowa (popieranie wybranych branż) & 23 & 1,39 & 1,37 & 23 & 1,22 & 0,90 \\
\hline
\end{tabular}

Tab. 3. Przydatność i realizacja działań z zakresu polityki gospodarczej w ocenie badanych przedsiębiorstw branży budowlanej

\begin{tabular}{|c|c|c|c|c|c|c|}
\hline \multirow{2}{*}{ Działania z zakresu polityki gospodarczej } & \multicolumn{3}{|c|}{ Przydatność } & \multicolumn{3}{|c|}{ Realizacja } \\
\hline & $\mathbf{L W}$ & ŚR & SDV & $\mathbf{L W}$ & ŚR & SDV \\
\hline - Obniżenie stóp procentowych kredytów na cele inwestycyjne & 31 & 3,32 & 0,65 & 30 & 1,20 & 0,71 \\
\hline - Zwiększenie dostępności kredytów na cele inwestycyjne & 31 & 3,26 & 0,73 & 30 & 1,27 & 0,64 \\
\hline - Wspieranie edukacji i szkoleń & 31 & 2,58 & 0,72 & 30 & 1,37 & 0,67 \\
\hline - Obniżenie stóp podatku dochodowego & 31 & 3,26 & 0,73 & 30 & 1,20 & 0,81 \\
\hline - Wspieranie małych i średnich firm & 31 & 3,39 & 0,67 & 30 & 0,93 & 0,64 \\
\hline $\begin{array}{l}\text { - Tworzenie płaszczyzn (stowarzyszenia, zrzeszenia) wymiany wiedzy, } \\
\text { informacji i doświadczeń pomiędzy firmami polskimi i zagranicznymi }\end{array}$ & 30 & 2,43 & 0,73 & 29 & 1,21 & 0,73 \\
\hline $\begin{array}{l}\text { - Zagraniczna polityka handlowa mająca na celu likwidację administra- } \\
\text { cyjno-prawnych barier dostępu do rynków zagranicznych }\end{array}$ & 29 & 2,72 & 1,03 & 28 & 0,96 & 0,74 \\
\hline - Ubezpieczenie kontraktów eksportowych & 29 & 2,72 & 0,92 & 28 & 1,11 & 0,83 \\
\hline - Dofinansowanie kredytów eksportowych & 27 & 2,56 & 0,89 & 27 & 0,78 & 0,75 \\
\hline - Tworzenie instytucji doradztwa eksportowego & 29 & 2,34 & 0,97 & 28 & 0,89 & 0,63 \\
\hline - Tworzenie instytucji informacji rynkowej & 30 & 2,53 & 0,82 & 29 & 1,14 & 0,69 \\
\hline - Sprzyjanie napływowi zagranicznych inwestycji bezpośrednich & 30 & 2,70 & 1,09 & 29 & 1,10 & 0,77 \\
\hline - Przyspieszenie rozwoju infrastruktury & 31 & 3,26 & 0,86 & 29 & 0,97 & 0,63 \\
\hline - Interwencja w pojedynczych firmach & 30 & 1,27 & 1,17 & 30 & 0,73 & 0,58 \\
\hline $\begin{array}{l}\text { - Wykorzystanie wszelkich możliwych środków ochrony firm polskich } \\
\text { w obliczu presji konkurencyjnej firm zagranicznych }\end{array}$ & 30 & 1,93 & 1,41 & 30 & 0,70 & 0,53 \\
\hline - Selektywna polityka przemysłowa (popieranie wybranych branż) & 30 & 1,53 & 1,07 & 30 & 0,87 & 0,82 \\
\hline
\end{tabular}


Tab. 4. Przydatność i realizacja działań z zakresu polityki gospodarczej w ocenie badanych przedsiębiorstw branży motoryzacyjnej

\begin{tabular}{|c|c|c|c|c|c|c|}
\hline \multirow{2}{*}{ Działania z zakresu polityki gospodarczej } & \multicolumn{3}{|c|}{ Przydatność } & \multicolumn{3}{|c|}{ Realizacja } \\
\hline & $\mathbf{L W}$ & ŚR & SDV & $\mathbf{L W}$ & ŚR & SDV \\
\hline - Obniżenie stóp procentowych kredytów na cele inwestycyjne & 21 & 3,05 & 0,67 & 21 & 1,33 & 1,06 \\
\hline - Zwiększenie dostępności kredytów na cele inwestycyjne & 21 & 3,10 & 0,77 & 21 & 1,38 & 0,86 \\
\hline - Wspieranie edukacji i szkoleń & 21 & 2,33 & 0,86 & 21 & 1,43 & 0,87 \\
\hline - Obniżenie stóp podatku dochodowego & 21 & 3,05 & 0,59 & 21 & 1,62 & 0,80 \\
\hline - Wspieranie małych i średnich firm & 21 & 2,81 & 0,81 & 21 & 1,48 & 1,17 \\
\hline $\begin{array}{l}\text { - Tworzenie płaszczyzn (stowarzyszenia, zrzeszenia) wymiany wiedzy, } \\
\text { informacji i doświadczeń pomiędzy firmami polskimi i zagranicznymi }\end{array}$ & 21 & 2,14 & 1,11 & 21 & 1,24 & 1,00 \\
\hline $\begin{array}{l}\text { - Zagraniczna polityka handlowa mająca na celu likwidację administra- } \\
\text { cyjno-prawnych barier dostępu do rynków zagranicznych }\end{array}$ & 21 & 2,67 & 0,86 & 21 & 1,48 & 0,93 \\
\hline - Ubezpieczenie kontraktów eksportowych & 21 & 2,67 & 0,86 & 21 & 2,05 & 1,20 \\
\hline - Dofinansowanie kredytów eksportowych & 21 & 2,76 & 0,62 & 21 & 1,86 & 1,01 \\
\hline - Tworzenie instytucji doradztwa eksportowego & 21 & 2,48 & 0,98 & 21 & 1,57 & 0,98 \\
\hline - Tworzenie instytucji informacji rynkowej & 21 & 2,48 & 0,93 & 21 & 1,48 & 0,93 \\
\hline - Sprzyjanie napływowi zagranicznych inwestycji bezpośrednich & 21 & 2,29 & 1,01 & 20 & 1,25 & 0,85 \\
\hline - Przyspieszenie rozwoju infrastruktury & 21 & 2,67 & 0,80 & 21 & 1,33 & 0,91 \\
\hline - Interwencja w pojedynczych firmach & 20 & 0,90 & 0,97 & 20 & 0,85 & 0,75 \\
\hline $\begin{array}{l}\text { - Wykorzystanie wszelkich możliwych środków ochrony firm polskich } \\
\text { w obliczu presji konkurencyjnej firm zagranicznych }\end{array}$ & 21 & 2,10 & 1,04 & 21 & 0,90 & 0,77 \\
\hline - Selektywna polityka przemysłowa (popieranie wybranych branż) & 21 & 1,43 & 1,29 & 21 & 1,29 & 1,15 \\
\hline
\end{tabular}

szego kierownictwa (podmioty badania), w badaniu zastosowano metodę pogłębionego wywiadu indywidualnego, przy wykorzystaniu kwestionariusza stanowiącego podstawowe narzędzie badawcze podczas rozmowy.

\section{Instrumenty polityki gospodarczej - punkt widzenia przedsiębiorstw}

0 łówną przesłanką polityki gospodarczej państwa powinno być wypracowywanie odpowiednich warunków do rozwoju podmiotów gospodarczych działających na terenie danego kraju. Ich dobry rozwój oraz wzrost liczby nowych przedsiębiorstw świadczy o dobrym klimacie inwestycyjnym w danym kraju, który zazwyczaj „,przyciaga” nowejednostki, zarówno te z kraju, jak i z zagranicy.

Państwo ma do dyspozycji wiele instrumentów pomagających w osiagganiu powyższych celów gospodarczych. Ocena przydatności niektórych z nich oraz realizacji dokonana przez wszystkie firmy należące do próby została przedstawiona w tabeli 1 .

Większość działań z zakresu polityki gospodarczej państwa uzyskała dobre lub bardzo dobre oceny pod względem ich przydatności. Najwyżej oceniono działania m.in. zmierzające w kierunku obniżenia stóp procentowych kredytów na cele inwestycyjne; zwiększenia dostępności tych kredytów; obniżenia stóp podatku dochodowego; wspierania małych i średnich firm oraz przyspieszenia rozwoju infrastruktury. Z kolei najniższą ocenę pod względem przydatności wskazano przy działaniu polegającym na interweniowaniu państwa w pojedynczych firmach oraz selektywnej polityce przemysłowej polegającej na popieraniu wybranych branż. Podobne zapotrzebowania na poszczególne działania państwa obserwowane są we wszystkich badanych branżach: budowlanej, motoryzacyjnej oraz spożywczej. Przedstawiają to wyniki badań dotyczące poszczególnych branż (por. tabele od 2 do 4).

Wysoka ocena przydatności instrumentów polityki gospodarczej nie jest równoznaczna z wysoką ocena stopnia praktycznej realizacji tych działań. Niestety ta druga została oceniona na dość niskim poziomie (przedział pomiędzy niskim i średnim stopniem realizacji) we wszystkich badanych branżach.

Omówione powyżej wyniki przedstawiają obraz sytuacji polskiego rynku w zakresie wsparcia rozwoju podmiotów gospodarczych przez państwo. Niestety nie jest to obraz przedstawiony w kolorowych barwach. Mimo że przydatność wielu działań i zadań uzyskała relatywnie wysokie oceny, to w odniesieniu do ich zastosowania w praktyce poziom oceny jest bardzo niekorzystny.

Zestawienie wyników badania z 2004 roku z badaniami nad przydatnością i realizacją środków polityki gospodarczej prowadzonymi w latach: 1993, 1995 i 2000 (por. [1 s. 186 i następne i 2] wskazuje na duże podobieństwo obserwacji. I tak, w badaniach prowadzonych w 1993 r., jako trzy najbardziej przydatne metody pobudzania eksportu wskazywano: pomoc w dotarciu do informacji o rynkach, ulgi eksportowe i gwarancje kredytowe. W 1995 r. wśród najbardziej pożądanych metod pobudzania eksportu znalazły się: pomoc w pozyskaniu informacji o rynkach, likwidacja 
administracyjno-prawnych barier dostępu do rynków zagranicznych przez zawieranie umów międzynarodowych oraz prowadzenie doradztwa eksportowego. Ocena realizacji postulowanych działań była również bardzo niska.

W tych wcześniejszych badaniach pytano także o znaczenie barier instytucjonalnych dla procesu przystosowywania się przedsiębiorstw do warunków gospodarki rynkowej. Barierami o największym znaczeniu w roku 1993 okazały się: niestabilność prawa, nieegzekwowanie przepisów prawa, niesprawność sądownictwa, przestarzałe prawo, niesprawny system bankowy, niesprawna telekomunikacja, niesprawna informacja, niesprawny rynek kapitałowy, niekompetentna administracja, brak zaufania do partnerów gospodarczych. W 1995 roku ocenę wyraźnie przekraczającą średni poziom przyznano już tylko niestabilności prawa oraz niesprawnemu rynkowi kapitałowemu. W badaniach z lat: 1993 i 1995 pytano także o najwłaściwszy zakres ingerencji rządu w działalność gospodarczą. W 1993 roku 64,4\% badanych opowiedziała się za zasadnością prowadzenia przez rząd zróżnicowanej branżowo, selektywnej polityki przemysłowej. W roku 1995 odsetek zwolenników takiej polityki zmniejszył się o około 5\%. Bardzo mały odsetek respondentów popierał bezpośrednią interwencję w firmach $(5,2 \%$ i $3,4 \%)$. Zauważalnie wzrosło natomiast poparcie dla polityki liberalnej, ograniczającej działania władz gospodarczych do wykorzystania instrumentów o charakterze makroekonomicznym $(29,8 \%$ i 37,3\% zwolenników odpowiednio w 1993 i 1995 roku).

W badaniach z roku 2000 (por. [1 s. 136-137]), w kategorii najbardziej przydatnych środków polityki gospodarczej w odniesieniu do zmniejszania luki konkurencyjnej najwyższe oceny uzyskały: reforma podatkowa, potrzeba szybkiego rozwoju infrastruktury, wspieranie tworzenia i rozwoju małych i średnich przedsiębiorstw, zwiększenie elastyczności rynku pracy, budowanie systemów informacji o rynkach, prywatyzacja, edukacja i szkolenia. Podobnie jak to było $\mathrm{w}$ badaniach wcześniejszych, ankietowani menedżerowie $\mathrm{z}$ rezerwą odnieśli się do interwencji państwa w pojedynczych firmach oraz do prowadzenia selek- tywnej polityki przemysłowej. Ocena realizacji tych i innych zadań polityki gospodarczej, o które pytano, wypadła także znacznie poniżej oczekiwań.

\section{Wnioski}

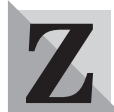
arówno wyniki uzyskane w roku 2004, jak i analiza wcześniejszych badań opinii polskich przedsiębiorstw na temat instrumentów polityki gospodarczej prowadzi do wniosku, że w okresie transformacji postrzeganie polityki przez firmy prawie się nie zmienia. Niezmiennie mamy do czynienia z dużymi oczekiwaniami i niskim stopniem ich zaspokojenia. Na przestrzeni tych lat zauważyć można jednak konsekwentny spadek poparcia dla bezpośrednich interwencji w pojedynczych firmach, selektywnej polityki przemysłowej oraz polityki ochrony przed konkurencją firm zagranicznych. Pozostaje mieć nadzieję, że umacnianie się liberalnego punktu widzenia na rolę władz gospodarczych stanie się przesłanką do zmniejszenia liczby zadań stawianych przed polityką gospodarczą i w konsekwencji większej koncentracji wysiłków i zasobów na realizacji priorytetowych zadań z zakresu uporządkowania sfery instytucjonalnej i rozwoju infrastruktury.

prof. dr hab. Marian Gorynia dr Matgorzata Bartosik-Purgat,

dr Barbara Jankowska, dr Radostaw Owczarzak Katedra Handlu Międzynarodowego Akademia Ekonomiczna w Poznaniu

\footnotetext{
*) Opracowanie powstało w ramach realizacji projektu badawczego Komitetu Badań Naukowych pt. Strategie firm polskich wobec ekspansji inwestorów zagranicznych (nr 2 H02D 011 24).
}

\section{BIBLIOGRAFIA}

[1] GORYNIA M. [2000], Zachowania przedsiębiorstw w okresie transformacji. Mikroekonomia przejścia, Poznań, Wydawnictwo Akademii Ekonomicznej w Poznaniu.

[2] Luka konkurencyjna na poziomie przedsiębiorstwa a przystapienie Polski do Unii Europejskiej [2002], M. GORYNIA (red.), Poznań, Wydawnictwo Akademii Ekonomicznej w Poznaniu. 